\title{
REVIEW \\ Robert Bonfil, Oded Irshai, \\ Guy G. Stroumsa, and Rina Talgam, Eds. \\ Jews in Byzantium: \\ Dialectics of Minority and Majority Cultures
}

(Leiden and Boston: Brill, 2012), hardcover, xvi + 1010 pp.

Demetrios E. Tonias

This edited volume represents a comprehensive examination of Jewish life in the regions of the Eastern Roman (Byzantine) Empire from the time of Constantine I in the fourth century to the fall of Constantinople to the Ottoman Turks in the fifteenth century. The previous absence of such a study constituted a serious lacuna in both Byzantine and Jewish studies, with the notable exceptions of the classic works on the subject by Joshua Starr, Andrew Sharf, and Steven Bowman. The volume is divided into three parts and is composed of thirty-five articles from thirty-one different contributors. Part I, "Setting the Stage," contains nine articles on the historical experience of Jews in the Greek-speaking Christian East. These articles examine the social, cultural, and economic conditions that impacted Jewish life throughout the eastern Mediterranean. Part II, "Cultural Encounters and Transmission of Knowledge," is composed of sixteen articles on the literary and artistic traditions of Jews in a region known for its iconographic art forms and vibrant textual tradition. Part III, "Images," is comprised of ten articles on the ways in which Christians and Jews viewed each other and how these perspectives were reflected in their respective traditions (e.g., the genre of Byzantine world chronicles, Jewish liturgical poetry [Piyyut], and Christian hagiographic material).

One cannot overstate the importance of this volume for scholars of the Byzantine Empire and Judaism. As the editors correctly recognize, the dearth of scholarship on Byzantine 
Jewry results from the dim view that Western and Jewish scholars previously held with regard to Byzantium. A quick scan of the footnotes gives an indication of how dependent the present volume is on the previous work of the aforementioned Starr, Sharf, and Bowman, scholarship completed in 1936, 1971 , and 1985, respectively. While there has certainly been growth in related research in the years since those works were completed, the present volume goes a long way toward synthesizing the efforts of more recent scholars and that of their predecessors. Moreover, it offers both Byzantinists and Jewish scholars an essential resource. Indeed, the editors of Jews in Byzantium have provided scholars with a research tool which, as an edited volume comprised of articles from scholars of varied backgrounds, is much more comprehensive than the works that preceded it.

The book as a whole reflects the challenges associated with any examination of Jewish life in the Greek-speaking Christian east. A common lament among the authors is the paucity of sources, especially Jewish ones. As Oded Irshai notes in his article, apart from "scanty references in fragmentary collections of rabbinical legal rulings, Midrashic texts, liturgical poetry, and apocalyptic treatises, our main sources of information on the life and culture of the Jews of this period are Christian" (p. 20). The authors therefore often rely upon Christian sources.

As the volume's subtitle indicates, much of the description of Jewish life in Byzantium appeared within the context of a Jewish minority living in a majority-Christian society. The articles of Part I chart the subtle and radical ways in which Jewish life was transformed as the state shifted from a Roman society rooted in the ancient Greco-Roman religious cult to one that self-identified as a Christian Roman state and saw itself as a successor to the pagan society which preceded it. Despite these changes, Jews, although a religious minority, were nevertheless formed by and members of that Roman state. Of particular note in this regard are the sections on Byzantine law and economy, which trace the evolution of Jewish life as the state took on a decidedly Christian character. Throughout, the 
authors pay close attention to context. For example, they are careful to differentiate between the periods of Justinian, Heraclius and the later Palaeologans, as well as between Constantinopolitan Jewry, Alexandrian Jewry, and Jews in the northernmost reaches of the Empire.

The examination of Jewish life in Byzantium, by definition, is a study of the effects of acculturation. As ambiguous as that term itself is, this ambiguity is amplified by the natural tendency of Jews to resist such assimilation. In this regard, the editors have done an excellent job pointing out where Jewish life, especially in terms of its literary and artistic expression adopted, adapted, and resisted the surrounding culture. Specific articles which discuss Jewish poetic expression in the form of Piyyut, the confluence of languages in Jewish life (both in discourse and worship), and the Jewish application of iconography, manuscript illumination, and synagogue decoration all serve to place the historical discussion in its proper context. These articles also demonstrate the uniqueness of Byzantine Jewish life when viewed against the backdrop of the broader Jewish world.

Another welcome aspect of the book is the presentation of the multicultural tableau of Byzantine society. From the seventh century onward, the rise of Islam created a third, major cultural force with its own particular influence on Jewish thought and life. There is a general concern on the part of the editors and the authors that Byzantine Jewish life be situated within the broader cultural milieu. Thus, the depiction of Jews in Muslim literary sources is as important as that found in Byzantine ones. The sections dealing with the ways in which Jews, Christians, and Muslims portrayed the other as part of their literary and artistic expression underscore the importance of this activity, especially in light of the lack of primary source material on the subject.

The volume is a massive yet necessary undertaking. As with any edited volume, the presentation of the material can sometimes seem a bit eclectic and uneven, but the editors 
nevertheless did a fine job overall organizing the variety of topics into cogent divisions. Jews in Byzantium is an essential resource for students of the subject and should spur further interest in an important aspect of Jewish life that for far too long has languished in the remote corners of Byzantine and Jewish studies. 